\title{
CONSULTING IN INCREASING INNOVATIVE ACTIVITIES OF ENTERPRISES OF UKRAINE
}

\author{
Natalia Yevtushenko ${ }^{1}$, Anatoliy Salo²
}

\begin{abstract}
The purpose of the article is to study economic phenomena and processes in Ukraine in order to substantiate the need to intensify innovative activity on its territory and to search for promising opportunities to increase the competitiveness of Ukrainian enterprises during the political and economic crisis. Measurement of the level of innovative development of Ukrainian enterprises was carried out using data for a nine-year period of time (2010, 2011, 2012, 2013, 2014, 2015, 2016, 2017, 2018, 2019). Methodology. The use of economic, abstract and logical research methods through methods of analysis, synthesis and graphical presentation made it possible to assess the level of innovative development of Ukrainian enterprises for the main international rating and macroeconomic indicators. Results. The content of the concept of "innovative activity" was clarified, which made it possible to highlight the main directions of innovative development of enterprises in the country. A methodology for conducting a step-by-step assessment of the level of innovative development of enterprises in Ukraine through the criteria that determine the profile of the National Innovation System of Ukraine is proposed. According to the results of the assessment, it has been found that during the analysed period, Ukraine's positions in The Global Competitiveness Index in the context of individual rating indicators do not have stability and are positioned at the level of underdeveloped countries. At the macroeconomic level of Ukraine, this is confirmed by the annual decrease in the part of expenses for the implementation of innovative developments in the structure of GDP expenditures to a critically low level. In the process of assessing the costs of performing innovative developments by type of work, it has been found that the most funded type in Ukraine is scientific and technical (experimental) developments. Practical implications. The results of the assessment confirm the drop in the level of innovative activity of Ukrainian enterprises, the low efficiency of the National Innovation System, and explain the passive role of the state and the further lag of the country in technological development from the developed countries of the world. In such conditions, there is the need to attract consulting companies to increase innovative activity. Value/originality. A methodology for assessing the level of innovative development of Ukrainian enterprises has been formed according to the results of which it is proposed to use consulting as an effective tool of the National Innovation System in order to increase the competitiveness of Ukrainian enterprises.
\end{abstract}

Key words: consulting, innovation, competitiveness, national innovation system, strategy, enterprises.

JEL Classification: F63, G29, 011, O30

\section{Introduction}

At the present stage of development of Ukraine, the stimulation of innovative activity is one of the primary factors of structural restructuring and accelerated economic growth. The basis of the innovation activity of enterprises is innovation, which at the legislative level is an effective tool for increasing the socioeconomic growth of any country. Without a developed innovation market, the normal functioning of a modern market economy based on technical, technological and managerial innovations is impossible. Unfortunately, the innovation market has been the weakest link in the Ukrainian economy due to imperfections in the mechanism of its financing and management. The deficit of financial resources combined with ineffective management methods both at macro and at micro levels is becoming the main problem that hinders the innovative development of domestic enterprises and the country as a whole.

So today, the situation continues to be relevant for solving the economic problem of the election of alternative directions for enhancing the innovative

\footnotetext{
Corresponding author:

${ }^{1}$ State University of Telecommunications, Ukraine.

E-mail: evtushtnko.13.nat@gmail.com

ORCID: https://orcid.org/0000-0001-8865-8365

${ }^{2}$ State University of Telecommunications, Ukraine.

E-mail: anatolijakovi4@gmail.com
} 
activity of enterprises in Ukraine, which in the future will ensure the stable growth of the country, contribute to an increase in labour productivity and competitiveness of domestic goods.

\section{Literature review}

\subsection{Formation of the National Innovation System: foreign experience and Ukrainian realities}

The concept of National Innovation System (NIS) and innovative development of enterprises was formed in world practice in the 1980s. Foreign scientists D. Archibugi, J. Howells, J. Michie (Archibugi, Howells \& Michie, 1999), R. Coombs, M. Harvey, B. S. Tether (Coombs, Harvey, \& Tether, 2003) substantiate that the features of modern NIS in the global economy are manifested through the synthesis of the following theoretical propositions:

1. General systems theory, according to which the system is an integrity, has certain boundaries, and in which there are hierarchical relationships.

2. The innovative theory of J. Schumpeter, the essence of which is that the engine of progress is innovation, that is, fundamentally new goods, technology, forms of production and exchange.

3. D. North's theory of institutional change, which substantiates that institutions directly and indirectly affect both knowledge and technology.

Taking into account the main provisions of theoretical concepts on the content of NIS, it is customary to define it as:

- a network of institutions in the public and private sectors, the interaction and activities of which are aimed at initiating, importing, modifying and disseminating new technologies (Freeman, 1995);

- organizations and institutions involved in the search and research, which interact in the process of production, distribution and use of new, economically beneficial knowledge, and also are located or originate from the territory of the nation state (Lundvall, 1992);

- set of institutions, the interaction of which determines the innovative productivity (efficiency) of national companies (Nelson \& Rosenberg, 1993);

- national institutions, their incentive structures and their competencies that determine the speed and direction of technical training (or the volume and composition of changes in activities in the country (Patel \& Pavitt, 1992);

- Network of different institutions that contribute to the development and diffusion of new technologies, creating a framework within which governments form and implement policies to influence the innovation process. It is a system of interconnected institutions that create, store and transfer knowledge and skills, which define new technologies (Metcalfe, 1995);
- all important economic, social, political, organizational, institutional and other factors that influence the development, diffusion and use of innovations (Edquist, 1997; 2005);

- a historically formed subsystem of the national economy, in which various organizations and institutions interact and influence each other in the process of implementing innovative activities (Galli \& Teubel, 1997).

In current business environment, activation issues continue to be relevant. Many foreign scientists, including M. Castells (Castells, 2010), T. Merriden (Merriden, 2003), I. Shugurova (Shugurova, 2010), I. Wilkinson, L. Young (Wilkinson \& Young, 2002), J. Rifkin (Rifkin, 2014), reveal the economic and legal aspects of technology transfer at the micro and macro levels.

In contrast to developed countries, the need to create NIS in order to intensify the innovative activities of domestic enterprises has not been legally defined for a long time in Ukraine. The term "National Innovation System" in the legislation of Ukraine was first formed in 2007 by the Resolution of the Verkhovna Rada "On the Recommendations of Parliamentary Hearings on the Topic: National Innovation System of Ukraine: Problems of Formation and Implementation" (Resolution of the Verkhovna Rada of Ukraine, 2007).

Later, in 2009, by the Order of the Cabinet of Ministers of Ukraine, the Concept for the Development of Ukrainian National Innovation System was approved, according to which the National Innovation System is interpreted as a set of legislative, structural and functional components (institutions) that are involved in the creation and application of scientific knowledge and technologies and determine legal, economic, organizational and social conditions for ensuring the innovation process (Order of the Cabinet of Ministers of Ukraine, 2009). The Order of the Cabinet of Ministers of Ukraine "On Approval of the Concept for the Development of the National Innovation System of Ukraine" dated 2009 includes such subsystems as: generation and dissemination of knowledge; innovative infrastructure (industrial and technological structures, financial structures, universities, educational centres, examination system, intellectual property protection system; certification, standardization and accreditation centres). Innovative activity is mastering, preparation and substantiation of the process, the introduction of innovations in the activities of enterprises.

Well known academicians of the National Academy of Sciences of Ukraine A. Amosha (Amosha, 2005), V. Heiets (Heiets, 2014), B. Paton (Paton, 2008) in their work presented the ways to create skills for the transition to an innovative model of development in Ukraine and proposed a set of measures and areas that can ensure the development of Ukraine as an innovative state. 
Well-known Ukrainian scientists A. Hudz ( $\mathrm{Hudz}$, 2018), I. Bahrova, O. Cherevko (Bahrova, \& Cherevko, 2014), L. Fedulova, V. Aleksandrova, Y. Bazhal (Fedulova et al, 2005) conduct numerous scientific studies to enhance the innovation activity of Ukraine, in which they determine the problems of development of the country's innovative economy, recommend directions of state policy, innovative models and systems for managing the innovative activity of Ukrainian enterprises in accordance with the change in values and guidelines for managing the digital economy.

V. Ivchenko (Ivchenko, 2007), L. Shapovalova (Shapovalova, 2011) substantiate the ways of development of the national innovation system of Ukraine, necessary for Ukrainian enterprises to build a competitive state economy.

K. Sichkarenko (Sichkarenko, 2015) complements the scientific heritage and emphasizes the formation of network cooperation in Ukraine for the purpose of efficient organization of technology transfer and determines the economic effect of its development. According to the results obtained, K. Sichkarenko substantiates the further development of the national innovation system on a network basis, proves the need for the development of a unified innovation and information network and its integration into similar international institutions.

Y. Bazhal (Bazhal, 2015) presents methodological and analytical generalizations of the modern experience of institutional support of organic cooperation between the state, universities and business structures in Ukraine regarding the implementation of innovative activities and substantiates the need to improve the existing innovation policy of Ukraine by creating and maintaining mechanisms of cooperative interaction between the state, universities and business structures.

\subsection{Consulting as an element of the National Innovation System of Ukraine: theoretical aspect}

The Order of the Cabinet of Ministers "On approval of the Concept for the development of the National innovation system of Ukraine" from 2009 includes such subsystems as (Order of the Cabinet of Ministers of Ukraine, 2009): 1) generation and dissemination of knowledge; 2) innovation infrastructure (production and technological structures, financial structures, universities, educational centres, examination system, intellectual property protection system; certification, standardization and accreditation centres).

In the current NIS of Ukraine, consulting is an element of the innovation infrastructure "Intellectual Property Protection System", the functions and tasks of which are related to ensuring the copyrights of inventors, patenting and licensing innovations. In this form, the direction of consulting at NIS does not disclose its full content. In the article, consulting will be considered as a coordinated process of creating intellectual products by professional consultants with their subsequent implementation in the activities of customer enterprises (Yevtushenko, 2017).

In the Western economic literature, consulting was considered by scientists as one of the most effective tools for managing the innovation activities of enterprises. M. Kubr, K. Makha, V. Riviera, S. Johnson, P. Blok and others made a significant contribution to the study of this direction. The theoretical and methodological basis of consulting was highlighted by modern foreign scientists: M. Kipping, F. Wickham, M. Sharko, E. Shane, D. Gable, L. Greiner, E. Utkin, V. Aleshnikova, A. Blinov, G. Marinka, A. Posadsky, J. Prigogine, V. Rapoport and others. In the context of globalization, transformations are reflected in the works by such domestic scientists as V. Verba, S. Dunda, N. Yevtushenko, T. Reshetnyak, S. Kozachenko, V. Novitsky etc.

Paying tribute to the developments of foreign and domestic scientists, carried out in the field of the theory of national innovation systems and the organization of ensuring the country's innovative development using consulting companies, today they have not found their final decision. Many issues on enhancing the innovation activity of enterprises in Ukraine and ways of interaction of consulting with it are relevant and require a comprehensive study.

\section{Methodology and research methods}

The development, preparation and justification of the process of introducing innovations into the activities of enterprises are characterized as innovative activities. According to the Law of Ukraine "On Innovation Activity”, innovations, newly applied and/or improved competitive technologies, products or services, as well as organizational and technical solutions of production, administrative, commercial or other nature, significantly improve the structure and quality of production and/or social sphere (Law of Ukraine, 2002).

In a general sense, "innovative activity" is defined as a process aimed at the development and implementation of the results of completed research and development or other scientific and technical achievements into a new or improved product sold on the market, into a new or improved technological process used in practice and related additional research and development (Skripko, 2011). On the other hand, innovative activity is understood as all scientific, technological, organizational, financial and commercial actions that actually lead to the implementation of innovations or are conceived for this purpose. Innovation activities are all 
scientific, technological, organisational, financial and commercial steps which actually, or are intended to, lead to the implementation of innovations (Hnylyanska et al, 2013).

In the narrow sense, innovation activity is the process of creating, implementing and disseminating innovation (Ilyashenko, 2010). Innovation is an activity aimed at updating the existing one, creating and using a new competitive product (product, technology of production method) in order to better meet social needs (increasing labour productivity, product quality, reducing its cost, etc.) (Faychuk \& Faychuk, 2013).

In this case, we can conclude that the innovation activity is an activity associated with the use of the results of fundamental scientific research for the development of new products or technologies (improvement of existing products and technologies) and the subsequent commercialization of developments, that is, the production of new products of technological systems and their implementation in the markets.

Methods for assessing the level of innovative development of Ukrainian enterprises are based on the criteria, as well as an innovative Ukrainian profile of the national system (Yevtushenko, 2017). It is proposed to assess the level of innovative development of Ukrainian enterprises in the following stages:

1. Analysis of the rating indicators of Ukraine in The Global Competitiveness Index.

2. Assessment of the level of state financing of innovative activities in Ukraine.

3. Assessment of the level of innovative activity of industrial enterprises in Ukraine.

4. Analysis of the development of research personnel in Ukraine.

5. Providing recommendations for increasing the competitiveness and the level of innovative activity of Ukrainian enterprises.

\subsection{Analysis of rating indicators of Ukraine}

At the first stage of assessing the level of innovative development of Ukrainian enterprises, an analysis of Ukraine's rating indicators in The Global Competitiveness Index in the period 2010-2019 has been carried out, the results of which are given in Table 1.

According to the results of the analysis, it turned out that during the analysed period Ukraine occupied unstable positions in the rating of The Global Competitiveness Index, which in 2019 returned Ukraine to the level of 2016, which indicated the low efficiency of the state scientific, technical and innovation policy. The decline in the level of competitiveness of Ukraine at the international level can be traced in relation to countries such as Greece, 26 positions ahead of Ukraine in 2019, Georgia 11 positions more than in Ukraine in 2019, Turkey 21 positions more than in Ukraine in 2019 etc. These circumstances contribute to the classification of Ukraine in the list of "traditional underdeveloped" countries, along with Namibia and Honduras.

For a detailed clarification of the reasons for the fall of Ukraine's positions in The Global Competitiveness Index, an analysis was carried out for individual indicators included in this index: Financial market development (8), Market size (10), Business sophistication (11), Innovation (12) (Figure 1).

The analysis revealed that some of Ukraine's positions in The Global Competitiveness Index (2010-2019) are not stable, and some of them are deteriorating every year. Thus, in terms of the "Financial market development" component, Ukraine in 2019 fell by 53 positions in comparison to the indicators of 2010, and in terms of the "Market size" component - by 9 positions in comparison to 2010. At the same time, the review of legislative acts on business development

Table 1

Ukraine's rating according to the Global Competitiveness Index (2010-2019)

\begin{tabular}{|c|c|c|c|c|c|c|c|c|c|c|}
\hline $\begin{array}{l}\text { Position of Ukraine } \\
\text { among individual } \\
\text { countries }\end{array}$ & 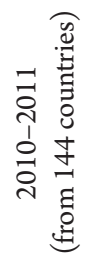 & 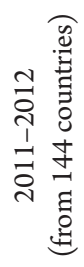 & 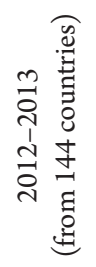 & 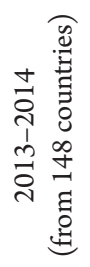 & 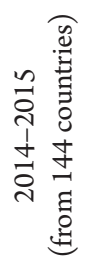 & 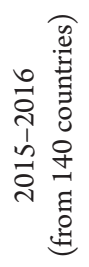 & 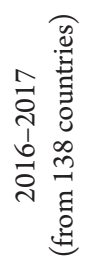 & 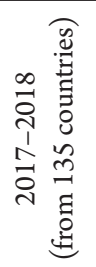 & 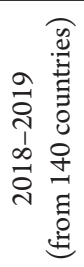 & 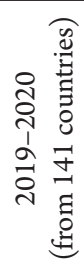 \\
\hline China & 27 & 26 & 29 & 29 & 28 & 28 & 28 & 28 & 28 & 28 \\
\hline Poland & 39 & 41 & 41 & 42 & 43 & 41 & 36 & 37 & 37 & 37 \\
\hline Russia & 63 & 66 & 67 & 64 & 53 & 45 & 43 & 45 & 43 & 43 \\
\hline Greece & 83 & 90 & 96 & 91 & 81 & 81 & 86 & 87 & 57 & 59 \\
\hline Turkey & 61 & 59 & 43 & 44 & 45 & 51 & 55 & 58 & 61 & 61 \\
\hline Georgia & 93 & 88 & 77 & 72 & 69 & 66 & 59 & 67 & 66 & 74 \\
\hline Namibia & 74 & 83 & 92 & 90 & 88 & 85 & 84 & 90 & 100 & 94 \\
\hline Ukraine & 89 & 82 & 73 & 84 & 76 & 79 & 85 & 89 & 83 & 85 \\
\hline Honduras & 91 & 86 & 90 & 111 & 100 & 88 & 88 & 103 & 101 & 101 \\
\hline
\end{tabular}

Source: built by authors based on (World Economic Forum, 2010-2019) 


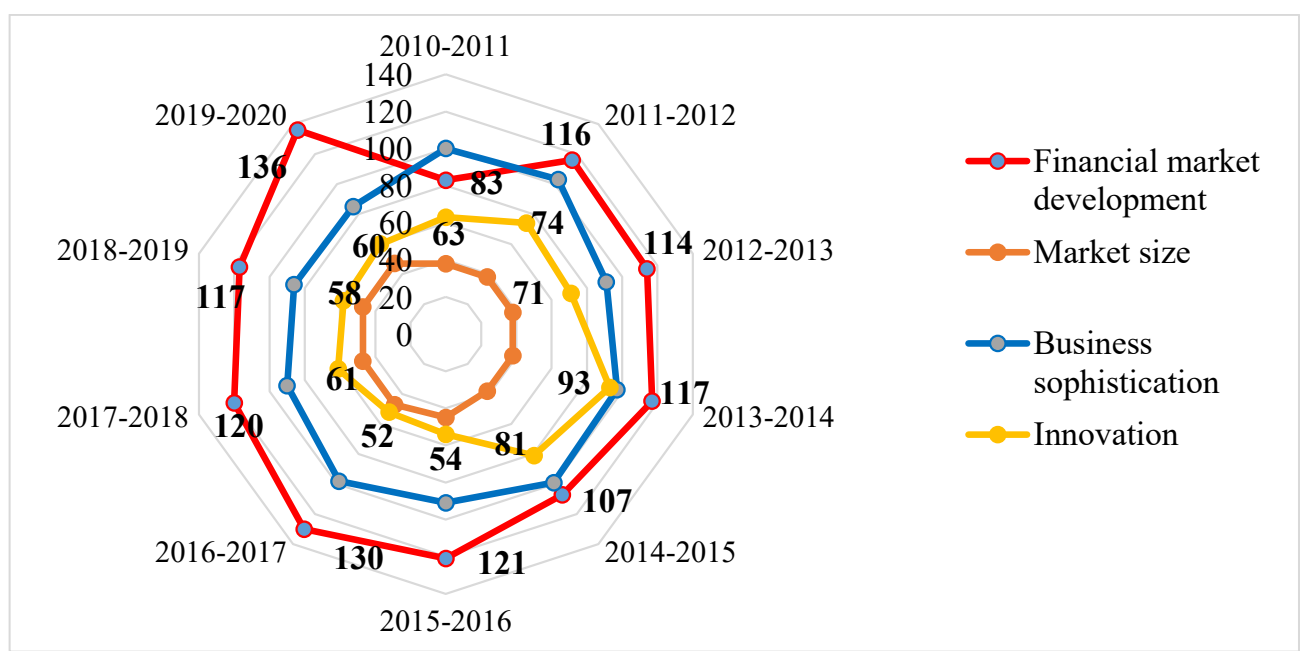

Figure 1. Selected indicators of the Global Competitiveness Index (2010-2019)

Source: built by authors based on (World Economic Forum, 2010-2019)

in Ukraine in 2019 contributed to an increase in the "Business sophistication" component by 15 positions compared to 2010 .

An important factor behind Ukraine's low rating in The Global Competitiveness Index (2010-2019), in addition to problems associated with imbalances in socio-economic and political development, was the policy of trade distortions. We believe that the low level of applied innovative technologies in the activities of enterprises led to the production of goods with low benefit, which affected the level of competitiveness of enterprises and the level of their purchasing power. However, the main problem that hinders the innovative development of the Ukrainian economy is the lack of financial resources.

\subsection{Assessment of the level of state funding for innovation in Ukraine}

In developed countries, it has been established that the state must ensure that the growth of expenditures on the development of scientific and technological progress and the encouragement of innovative activities of enterprises is ahead of the growth of the gross domestic product. According to the recommendations of the European Union countries, the share of expenditures on the implementation of the volume of scientific research in GDP is formed at the level of more than $2 \%$.

In this regard, the level of innovative development of Ukrainian enterprises has been assessed and we will determine the share of expenditures that the state allocates for innovation in the structure of Ukraine's GDP for the period 2000-2009 (Figure 2).

The analysis shown in Figure 2 shows that in the context of political, economic and institutional imbalances, low demand for innovations in Ukraine, there is an annual reduction in the share of spending on innovation development in GDP. Thus, during the analysed period, the share of expenses for the implementation of innovative developments in GDP decreased almost twice (by $0.32 \%$ ), in particular,

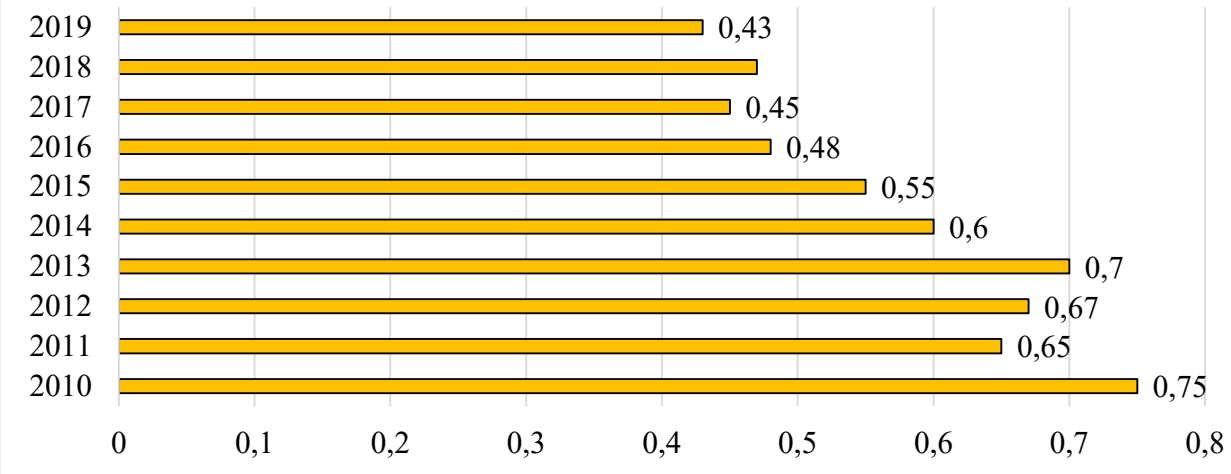

Figure 2. Share of spending on innovation development in GDP, \%

Source: built by authors based on (State Statistics Service of Ukraine, 2010-2019) 


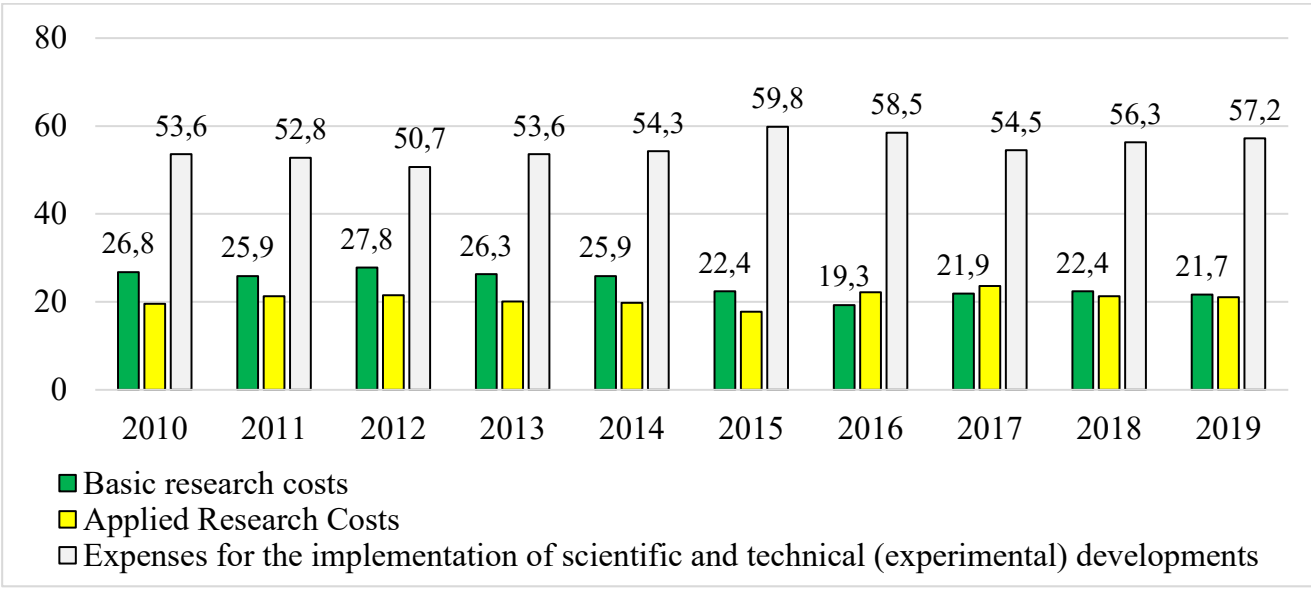

Figure 3. Dynamics of expenditures on scientific education and distribution by types (2010-2019), mln UAH

Source: built by authors based on (State Statistics Service of Ukraine, 2010-2019)

this share decreased from $0.75 \%$ in 2010 to $0.43 \%$ in 2019.

Such negative trends persisted despite the approved legislative standards. According to the Law of Ukraine "On Scientific and Scientific and Technology Activities", this level was set in the range from $1.7 \%$ to $2.5 \%$, except for defence expenditures (Law of Ukraine, 2015).

To identify the most significant areas of scientific research in Ukraine by type of work, we will analyse the level of costs for the implementation of fundamental, applied scientific, and technical developments for 2010-2019 (Figure 3).

The study has found that the most significant direction is scientific and technical (experimental) developments, the share of which is on average almost $61.25 \%$, respectively, of the total expenditures for scientific research and development in Ukraine. In developed countries, this figure reaches $70 \%$ (Paton, 2008). The volume of expenses for the implementation of applied research studies for the analysed period are practically unchanged (on average - $23.14 \%$ ). This example of partial research is carried out by basic research adjusted for analysis of the results by $5.1 \%$ and is calculated at the middle of $26.71 \%$; it is a widely used type of research presented in developments, typical research studies.

\subsection{Assessment of the level of innovation activity of industrial enterprises of Ukraine}

A similar drop in the level of innovation occurs among industrial enterprises in Ukraine. In this regard, the sources of financing the innovative activity of industrial enterprises of Ukraine for the period 2010-2019 have been analysed (Figure 4).

Analysis of statistical data shows that during the period under review, the main source of financing for innovative activities of industrial enterprises is the own funds of these enterprises, which constitute on average $87.4 \%$ of the total volume of financing for innovative activities, while the volume of state funds is $2.4 \%$, funds from non-resident investors $6.3 \%$, and funds from other sources $-15.0 \%$. Such a distribution of funds by sources of financing for innovative activities indicates the insignificant participation of the state in the development of innovative potential, despite the significant resource capacities of Ukraine.

Let us determine the proportion of industrial enterprises in Ukraine for the period 2010-2019, and the proportion of the volume of sold innovative products belonging to these industrial enterprises (Figure 5).

In the process of calculations, it turned out that the share of industrial enterprises that introduced innovations in Ukraine during 2010-2019 did not exceed $16 \%$ of the total number of enterprises in Ukraine. Moreover, the largest number of innovative types of products has been introduced at the enterprises of Zaporizhzhia, Lviv, Kharkiv, Dnipropetrovsk oblasts, and Kyiv.

During the period of independence, industrial enterprises of Ukraine have experienced crisis periods more than once. Thus, the proportion of enterprises that introduced innovations was very low in $2010-11.5 \%$ and in $2014-12.1 \%$, which was below the threshold value $(25 \%)$ and much lower than in developed countries (70-80\%) (Yevtushenko, 2017). The result of it was a drop in the share of the volume of sold innovative products in the total volume. By the end of 2019, this indicator decreased by $2.5 \%$ compared to 2010 and equalled the indicator of 2015.

In the current conditions, industrial enterprises of Ukraine find it difficult to carry out innovative activities associated with changes in technological processes and the release of innovative products (Figure 6). 
Vol. 7 No. 2, 2021

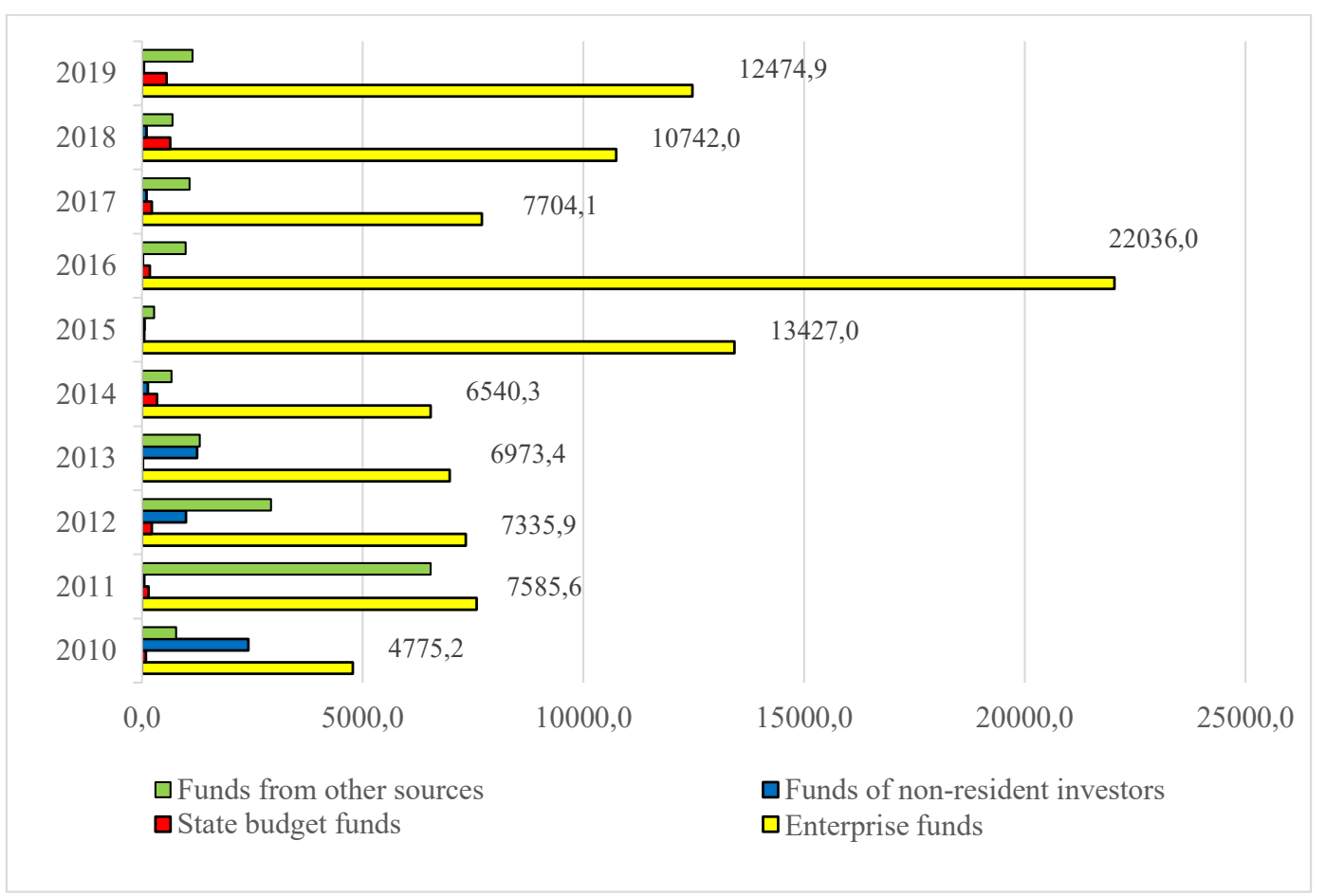

Figure 4. Dynamics of volumes of financing of innovative activity of industrial enterprises in Ukraine by sources (2010-2019), mln UAH

Source: built by authors based on (State Statistics Service of Ukraine, 2010-2019)

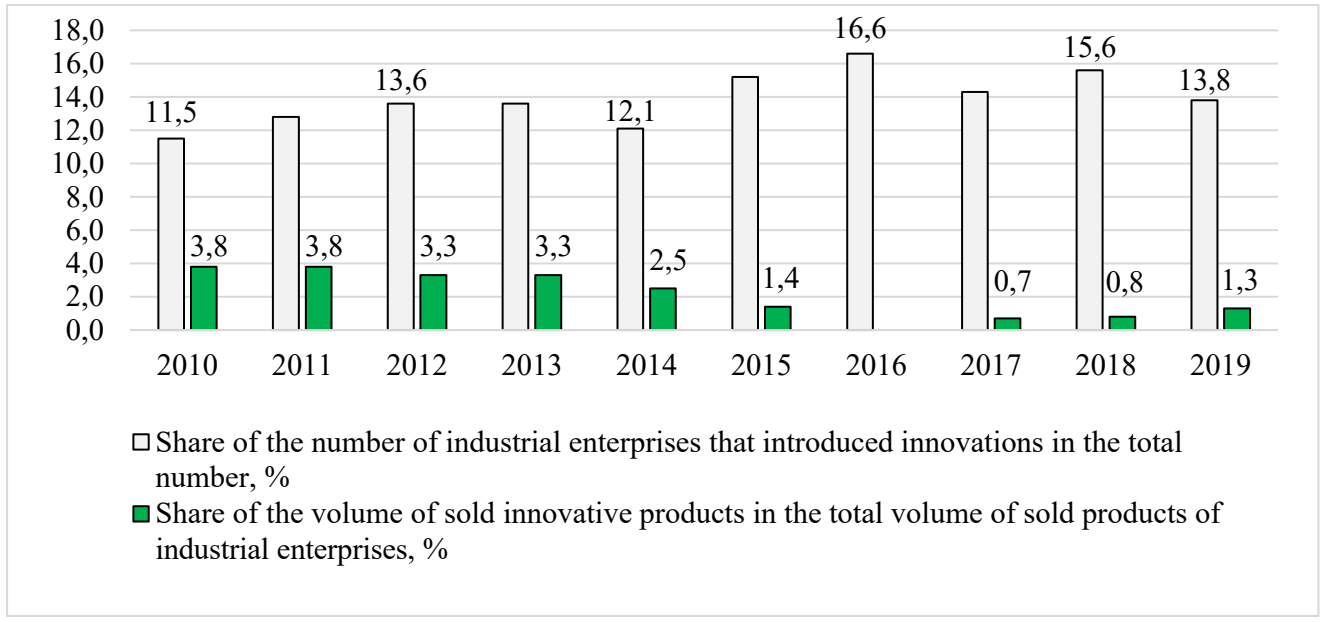

Figure 5. Dynamics of a part of the number of industrial enterprises and share of the volume of innovative products sold by them in 2010-2019, \%

Source: built by authors based on (State Statistics Service of Ukraine, 2010-2019)

In the process of analysing the data, the absence of a clear course for determining measures to improve innovation policy in Ukraine was revealed, where more than the number of technological processes for the production of these innovative products is being introduced in terms of quantity. So, on average, 3500 units of innovative products are being introduced into the activities of industrial enterprises, while the average number of new technological processes is 2324 units.

\subsection{Analysis of the development of research staff in Ukraine}

The next criterion that determines the profile of the National Innovation System of Ukraine is human resources. Let us analyse the impact of research personnel in Ukraine on the enhancement of innovative activity (Figure 7). It has been established that the bulk of research fellows in Ukraine are formed by researchers - on average $78 \%$, the number of which at the end of 2019 decreased by 82.6 thousand people 


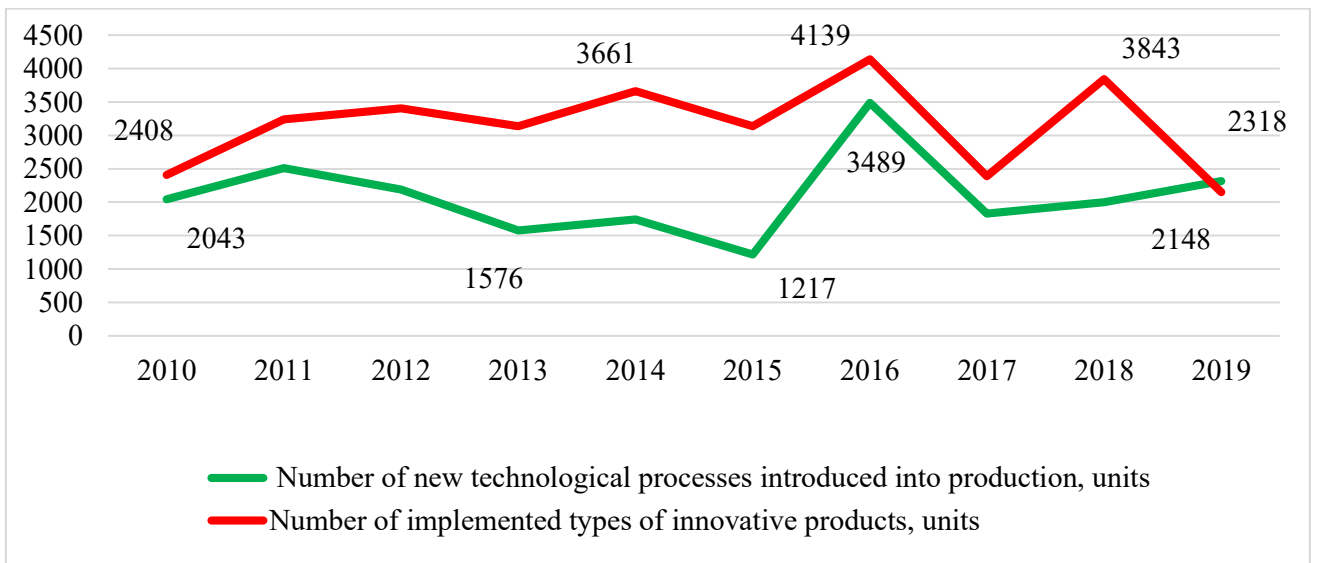

Figure 6. Dynamics of the number of introduced new technological processes and types of innovative products 2010-2019, units

Source: built by authors based on (State Statistics Service of Ukraine, 2010-2019)

in relation to 2010, and decreased by 43.2 thousand relative to 2015 .

Technicians account for an average of $10 \%$ of the total number of employees involved in research and development, the share of which decreases annually, in particular, in 2019 the number of technicians decreased by 12.6 thousand people compared to 2010. The number of researchers in the form of doctors of sciences and doctors of philosophy during the analysed period is shown in Figure 8.

It was found that, in contrast to developed countries, the proportion of doctors of philosophy (candidates of sciences) in Ukraine among the performers of research work was $27 \%$, and doctors of sciences $8.1 \%$. Moreover, more than half of the total number of doctors of sciences and doctors of philosophy carried out their research and development in organizations of the public sector of the economy, $39.1 \%$ - in higher education, $4.8 \%$ - in the business sector.
The reason for the reduction in the human scientific potential of Ukraine is outdated forms of organization of fundamental research, materially insecure jobs with little opportunities for career growth and professional recognition, a general underestimation by society of the role of fundamental research in the country's economic growth. So the minimum funding allocated for one scientist in the European Union is 50-55 thousand USD per year, in Ukraine 15 thousand USD (Holovinov, \& Kovtun, 2010).

\section{Recommendations}

According to the results of the study, the activation of innovative activity in Ukraine is slow and hazard. In these circumstances, increase of the competitiveness of Ukraine is possible only through the use of adaptive mechanisms to enhance innovation and the introduction of new resource-saving technologies

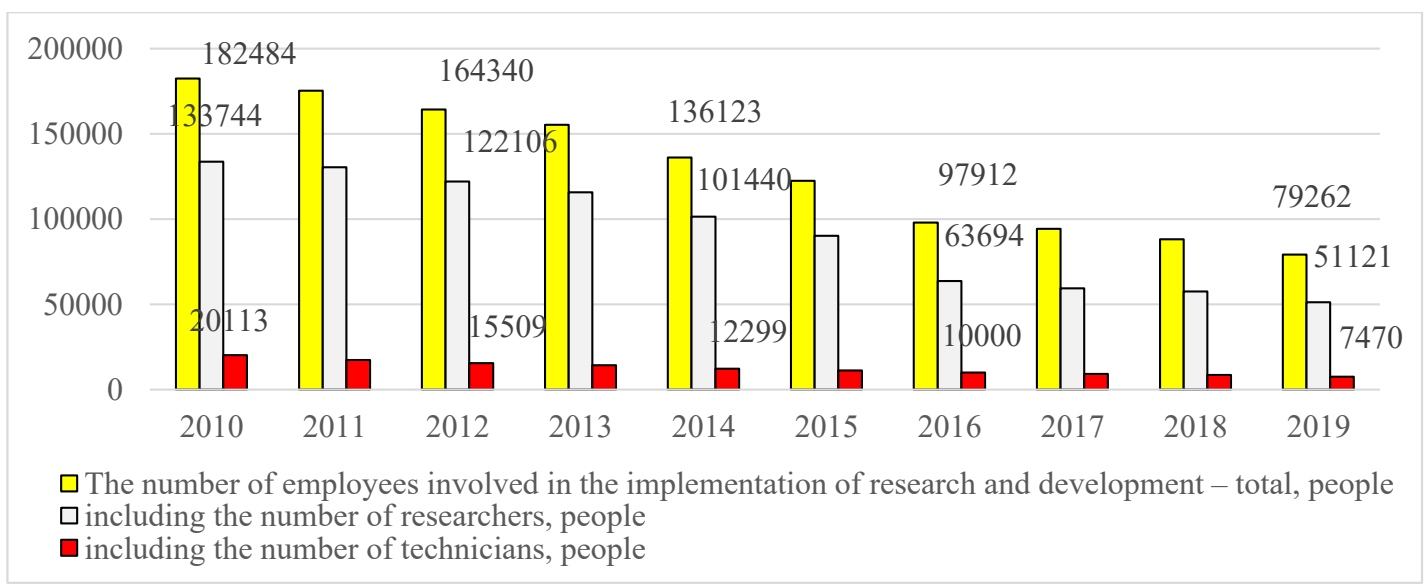

Figure 7. Dynamics of the number of employees involved in research and development, by categories of personnel for 2010-2019, people

Source: built by authors based on (State Statistics Service of Ukraine, 2010-2019) 


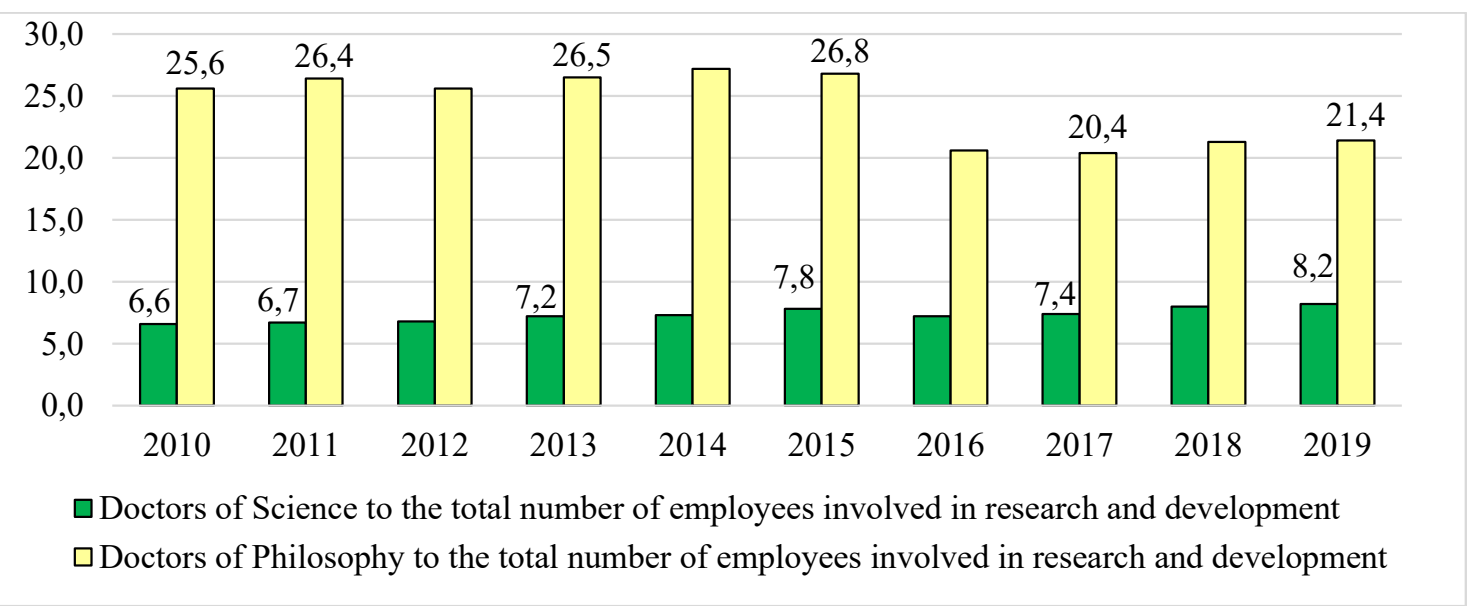

Figure 8. The number of doctors of sciences and doctors of philosophy involved in the implementation of scientific research in 2010-2019, persons

Source: built by authors based on (State Statistics Service of Ukraine, 2010-2019)

designed to improve the economic, social and environmental situation. Such activity is associated with the emergence of new relationships and interpenetration of economic, social and technical sciences, the creation and development of a specific conceptual apparatus.

Taking into account international experience, we believe that consulting is endowed with many characteristics that allow it to be presented in terms of a coordinated process of creating intelligent products for client enterprises by professional consultants in order to spread new technologies to ensure efficiency and the level of innovative development. (Yevtushenko, 2019). The place of consulting in the National Innovation System of Ukraine should be designated between the system of state regulation (institutions) of education; generation of knowledge; innovative infrastructure; production. In important systems, consulting can become an innovative representative of NIS and an active intermediary in the transfer of innovative technologies to the state and private economy (Figure 9).

In the process of interconnection with the main subsystems of NIS (government regulation; production; innovation infrastructure; education), consulting realizes its relations with consumers of services, taking into account the creation of consulting interaction. N. Yevtushenko proposed to understand "consulting interaction" as a professional communicative process between subjects of economic relations in the communicative space regarding the solution of problem situations of enterprises-customers of consulting services in accordance with increasing their potential in the field of management, operation and development (Yevtushenko, 2017; Yevtushenko, 2019).

In order to increase the efficiency of the enterprise of the customer the consulting company should carry out rational joint actions with the subsystems of the NIS in particular (Yevtushenko, 2019):

1. Process of transfer of intellectual products, taking into account fundamental and applied research, development, innovation in the production and technological sphere of the private sector.

2. Process of training the personnel of the customer enterprise to work in new conditions.

3. Process of attracting state-owned enterprises to work on examination, certification and standardization.

4. Process of developing financial ( $\operatorname{tax}$ ) schemes for the optimal use of the customer's capital for the implementation of innovative projects.

5. Procedure for the protection of their intellectual property.

6. Recommendations for minimizing risks in the development, implementation of innovative projects.

It is important to note that in order to implement the system of interconnections and interaction with the subsystems of NIS of Ukraine consulting; it is desirable to have access to the knowledge generation system in order to disseminate them through the subsystems of the innovation infrastructure and production, education and government regulation. This will help them develop in accordance with the strategies of innovative development specified in the directions of the state innovation policy.

\section{Conclusions}

Thus, the assessment of the level of innovative development of Ukrainian enterprises made it possible to identify the problems of innovative activity. The results of the analysis of international rating and macroeconomic indicators point to recessive processes in the Ukrainian economy, a drop in production and the level of innovation activity against the background 


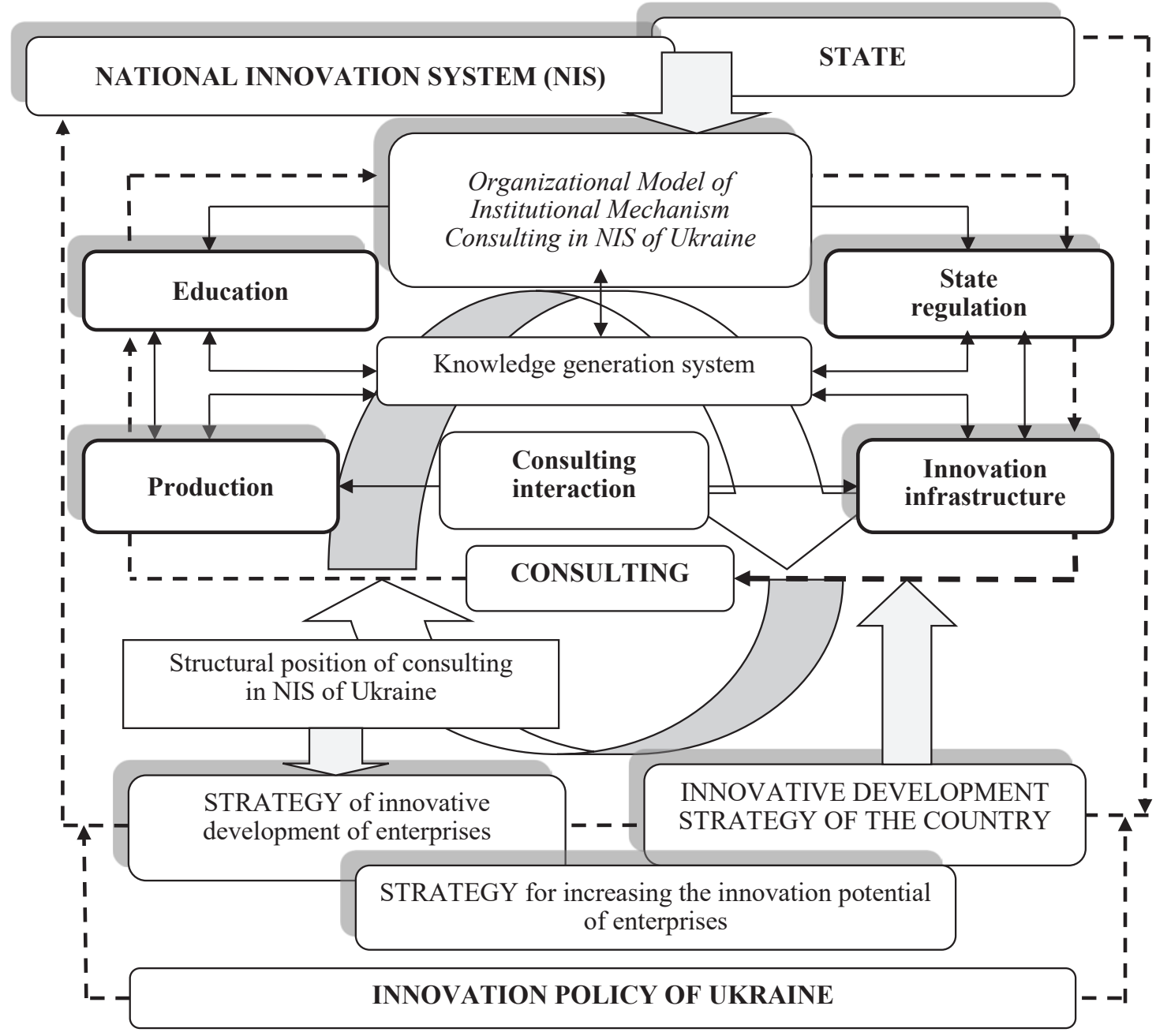

Figure 9. The system of interconnection and interaction of consulting with the main subsystems of the national innovation system of Ukraine

Source: (Yevtushenko, 2019)

of a decline in welfare in the country. Ukrainian enterprises are forced to independently adapt to changes by optimizing their activities in order to obtain a small but guaranteed profit. All this hinders the already development of innovations in Ukraine against the background of slow technical re-equipment of enterprises and a significant reduction in the human scientific potential of Ukraine.

To solve this problem, a scientific substantiation of the system of interconnections and interaction of consulting with the main subsystems of the NIS of Ukraine was carried out, in which consulting activities are considered as intermediary according to the structural position in this system, by developing and introducing innovations into production against the background of coordinating appropriate management decisions. The effective interaction of consulting as a separate element of the innovation infrastructure of NIS Ukraine should be aimed at implementing strategic directions for building up the innovative potential of Ukrainian enterprises, used by highly developed countries (USA, Great Britain, Germany, France, etc.).

The use of foreign experience in the implementation of consulting services in Ukraine will lay the foundation for increasing the competitiveness of the country's economy. The formation of the necessary internal conditions will make it possible to ensure an "innovative breakthrough" of the economy in the future to enter the category of competitive economies.

\section{References:}

Archibugi, D., Howells, J., \& Michie, J. (1999). Innovation systems in a global economy. Technology Analysis and Strategic Management, vol. 11(4), pp. 527-540. 
Amosha, O. I. (2005). Orhanizatsiino-ekonomichni mekhanizmy aktyvizatsii innovatsiinoi diialnosti v Ukraini [Organizational and economic mechanisms of intensification of innovation activity in Ukraine]. Industrial economics, vol. 5, pp. 15-21. Available at: http://dspace.nbuv.gov.ua/handle/123456789/3103 (in Ukrainian)

Bahrova, I. V., \& Cherevko, O. L. (2015). Innovatsiinyi rozvytok yak osnova realizatsii modelei staloho rozvytku natsionalnoi ekonomiky [Innovative development as a basis for the implementation of models of sustainable development of the national economy]. Scientific Bulletin of Kherson State University, vol. 11, no. 1, pp. 18-22. Available at: http://nbuv.gov.ua/UJRN/Nvkhdu_en_2015_11\%281\%29_5 (in Ukrainian)

Bazhal, Yu. M. (2015). Rozvytok innovatsiinoi diialnosti u znannievomu trykutnyku "derzhava - universytety promyslovist" [Development of innovation activity in the knowledge triangle "state - universities - industry"]. Economics and forecasting, vol. 1, pp. 76-88. Available at: http://nbuv.gov.ua/UJRN/econprog_2015_1_8 (in Ukrainian)

Castells, M. (2010). Information Age: Economics, Society, Culture. 2nd ed. Oxford: Wiley Blackwell.

Coombs, R., Harvey, M., \& Tether, B. S. (2003). Analysing distributed processes of provision and innovation. Industrial and Corporate Change, vol. 12(6), pp. 1125-1215.

Edquist, C. (1997). Systems of innovation approaches - their emergence and characteristics, C. Edquist (ed.). Systems of Innovation: Technologies, Organizations and Institutions. London: Pinter, pp. 1-35.

Edquist, C. (2005). 'Systems of innovation - perspectives and challenges', in J. Fagerberg, D. C. Mowery and R. R. Nelson (eds). The Oxford Handbook of Innovation, Oxford: Oxford University Press, pp. 181-208.

Ekonomichna statystyka / Nauka, tekhnolohii ta innovatsii [Economic Statistics / Science, Technology and Innovation]. State Statistics Service of Ukraine (2010-2019). Available at: http://www.ukrstat.gov.ua/ (in Ukrainian)

Faychuk, O. M., \& Faychuk O. V. (2013). Innovatsiynyy protses yak rushiyna syla ekonomichnoho zrostannya [Innovation process as a driving force of economic growth]. Business Inform, vol. 10, pp. 66-70. (in Ukrainian)

Fedulova, L. I, Aleksandrova V. P., \& Bazhal Yu. M. (2005). Innovatsiinyi rozvytok ekonomiky: model, systema upravlinnia, derzhavna polityka [Innovative economic development: model, management system, public policy]: monograph. Kyiv: Osnova. (in Ukrainian)

Freeman, C. (1995). The 'National system of innovation' in historical perspective. Cambridge Journal of Economics, vol. 19(1), pp. 5-24. doi: 10.1093/oxfordjournals.cje.a035309

Galli, R., \& Teubal, M. (1997). Paradigmatic shifts in national innovation systems. Edquist C (ed.). Systems of Innovation. Technologies Institutions and Organizations. London: Pinter, pp. 354-364.

Heiets, V. M. (2014). Instytutsiina obumovlenist innovatsiinykh protsesiv u promyslovomu rozvytku Ukrainy [Institutional conditionality of innovation processes in the industrial development of Ukraine]. Ukraine economy, vol. 12, pp. 4-19. Available at: http://nbuv.gov.ua/UJRN/EkUk_2014_12_2 (in Ukrainian)

Hudz, O., \& Prokopenko, N. (2018). The increase of enterprises' innovative development based on the network approach. Baltic Journal of Economic Studies, vol. 4, no. 1, pp. 99-105. doi: 10.30525/2256-0742/2018-4-1-99-105 Hnylyanska, L., Hryshchuk, A., Hurnyak, I., Zahvoyska, L., Makara, O., Petrynka, V., \& Yurynets, Z. (2013). Innovatsiinyi postup ekonomiky Ukrainy: problemy, tendentsii, potentsial zrostannia [Innovative progress of the Ukrainian economy: problems, trends, growth potential]: monograph. Lviv Polytechnic National University. Lviv: Liga-Press, 295 p. (in Ukrainian)

Holovinov, O. M., \& Kovtun, A. I. (2010). Priorytetni napriamy rozvytku i problemy finansuvannia innovatsiinoi diialnosti [Priority directions of development and problems of financing of innovative activity]. Available at: http://www.rusnauka.com/11_EISN_2010/Economics/64084.doc.htm (in Ukrainian)

Illyashenko, S. M. (2010). Marketynh. Menedzhment. Innovatsii [Marketing. Management. Innovations]: monograph. Sumy: Papyrus, 621 p. (in Ukrainian)

Ivchenko, V. (2007). Stanovlenie i razvitie natcionalnoi innovatcionnoi sistemy Ukrainy kak predposylka postroeniia konkurentosposobnoi ekonomiki gosudarstva [Formation and development of the national innovation system of Ukraine as a prerequisite for building a competitive economy of the state]. Development Strategy of Ukraine, vol. 1/2, pp. 246-252. (in Ukrainian)

Lundvall, B.-Å. (1992). National Systems of Innovation: Towards a Theory of Innovation and Interactive Learning. London: Pinter.

Merriden, T. (2003). Biznes put: Nokia. Sekrety uspekha samoi bystrorazvivaiushcheisia kompanii v mire [Business Way: Nokia. Secrets to the success of the fastest growing company in the world]. St. Petersburg: Publishing house «Krylov».

Metcalfe, J. S. (1995). Technology systems and technology policy in an evolutionary framework. Cambridge Journal of Economics, vol. 19(1), pp. 25-46.

Nelson, R. R. (1993). National Systems of Innovation: A Comparative Study, Oxford: Oxford University Press, pp. 3-21.

Order of the Cabinet of Ministers of Ukraine (2009). Pro skhvalennia Kontseptsii rozvytku natsionalnoi innovatsiinoi systemy [On approval of the Concept of development of the national innovation system]. Available at: http://search.ligazakon.ua/1_doc2.nsf/ (in Ukrainian) 
Patel, P., \& Pavitt, K. (1992). The innovative performance of the world's largest firms: some new evidence. Economics of Innovation and New Technology, 2, 91-102.

Paton, B. Ye. (2008). Nauka - innovatsiiam [Science - innovation]. Science and innovation, vol. 4, no. 5, pp. 19-20. (in Ukrainian)

Resolution of the Verkhovna Rada of Ukraine (2007). Pro Rekomendatsii parlamentskykh slukhan na temu: Natsionalna innovatsina systema Ukrainy: problemy formuvannia ta realizatsii [On the Recommendations of Parliamentary Hearings on the Topic: National Innovation System of Ukraine: Problems of Formation and Implementation]. Available at: http://zakon2.rada.gov.ua/laws/show/1244-16 (in Ukrainian)

Rifkin, J. (2014). Tretia promyshlennaia revoliutciia [The third industrial revolution]. Moscow: Alpina nonfiction, $410 \mathrm{p}$. (in Russian)

Shapovalova, L. (2011). Skladovi natsionalnoi innovatsiinoi systemy ta riven yikh rozvytku v Ukraini [Components of the national innovation system and the level of their development in Ukraine]. Bulletin of Taras Shevchenko National University of Kyiv, no. 121-122, pp. 94-98. (in Ukrainian)

Sichkarenko, K. O. (2015). Merezheva orhanizatsiia innovatsiinoi diialnosti: naukova dopovid [Networking organization of innovation activity: scientific report]. Kyiv: National Academy of Sciences of Ukraine, Institute of Economics and Forecasting, National Academy of Sciences of Ukraine. (in Ukrainian)

Shugurova, I. V. (2010). Politiko-pravovye aspekty transfera rossiiskikh tekhnologii za rubezh [Political and legal aspects of transfer of Russian technologies abroad]. Mezhdunarodnye protcessy - International processes, vol. 1, pp. 78-81. (in Russian)

Skripko, T. O. (2011). Innovatcionnyi menedzhment [Innovation management] Textbook. Kyiv: Knowledge, 432 p. Available at: https://pidru4niki.com/1584072019034/menedzhment/innovatsiyniy_menedzhment (in Ukrainian)

Wilkinson, I., \& Young L. (2002). On Cooperating: Firms, Relations and Networks. Sydney University of Technology Journal of Business Research. Available at: http://necsi.edu/events/iccs6/viewpaper.php?id=128

World Economic Forum. Ranking of the countries of the world according to the Global Competitiveness Index (2010-2019). Available at: https://gtmarket.ru/ratings/global-competitiveness-index

Yevtushenko, N. O. (2017). Komparatyvnyy analiz ponyattya «konsaltynhova vzayemodiya» [Comparative analysis of the concept of "consulting interaction"]. Economy. Management. Business. Kyiv: DUT, vol. 1, no. 19, pp. 42-50. (in Ukrainian)

Yevtushenko, N. O. (2017). Mekhanizm konsultatyvnoi vzaiemodii pidpryiemstv na rynku telekomunikatsiinykh posluh Ukrainy [The mechanism of consulting interaction of enterprises in the market of telecommunication services of Ukraine]: monograph. Kyiv: SIC GROUP, 535 p. (in Ukrainian)

Yevtushenko, N. O. (2019). Orhanizatsiino-ekonomichnyi mekhanizm konsultatynoi vzaiemodii pidpryiemstv Ukrainy [Organizational and economic mechanism of consulting interaction of Ukrainian enterprises] (doctoral dissertation), Kyiv: State University of Telecommunications.

Yevtushenko, N. O. (2017). Zatrebuvanist konsaltynhu yak okremoho elementa innovatsiinoi infrastruktury natsionalnoi innovatsiinoi systemy Ukrainy na rynku posluh [Demand for consulting as a separate element of the innovation infrastructure of the national innovation system of Ukraine in the services market]. Economy. Management. Business. Kyiv: DUT, vol. 3, no. 21, pp. 61-68. (in Ukrainian)

Law of Ukraine (2002). Pro Innovatsiinu diialnist [About Innovative activity]. Available at: https://zakon.rada.gov.ua/laws/show/40-15\#Text (in Ukrainian)

Law of Ukraine (2015). Pro naukovu i naukovo-tekhnichnu diialnist [About scientific and scientific and technical activity]. Available at: http://zakon5.rada.gov.ua/laws/show/848-19 